UDC 543.3

${ }^{*} Y e$. Sailaukhanuly ${ }^{1}$, B.N. Kenessov ${ }^{1}$, L. Carlsen ${ }^{1,2}$, D.H. Kamysbayev ${ }^{1}$

${ }^{1}$ Center of Physical Chemical Methods of Research and Analysis, al-Farabi Kazakh National University, Kazakhstan, Almaty

${ }^{2}$ Awareness Center, Denmark, Roskilde

*E-mail: s.erbolat@mail.ru

\title{
SPME GC/MS determination of organochlorine pesticides in water samples
}

Headspace solid phase microextraction (HS-SPME) in combination with gas chromatography and mass-spectrometry (GC/MS) was studied for analysis of water samples. The organochlorine pesticides (OCPs), p,p'-DDT, p,p'-DDD, and p,p'-DDE were collected and analyzed by GC/MS. To select of effective fiber coatings four types of SPME fibers were examined and compared. The parameters effecting the efficiency of HS-SPME such as extraction and pre-incubation time and extraction temperature, effect of solvent nature, ionic strength were studied to obtain optimal parameters. The method was developed using spiked water samples in a concentration range $10-500 \mathrm{ng} / \mathrm{L}$. The calibration curve was linear over the studied concentration range with $r \geq 0.9925$. The detection limits varied from 1.57 to $2.08 \mathrm{ng} / \mathrm{L}$. An authentic water samples from contaminated lake with OCPs were analyzed by developed method.

Keywords: solid phase microextraction, gas chromatography, mass-spectrometry, organochlorine pesticides.

\section{Е. Сайлауханулы, Б.Н. Кенесов, Л. Карлсен, Д.Х. Камысбаев \\ Определение хлорорганических пестицидов в воде методом ТФМЭ/ГХ/МС}

Была изучена твердофазная микроэкстракция (ТФМЭ) в сочетании с газовой хроматографией с массспектрометрическим детектированием (ГХ/МС) для анализа воды. Были отобраны и проанализированы хлорорганические пестициды (ХОП), такие, как р,p-ДДТ, p,p-ДДД и p,p-ДДЭ методом ГХ/МС. Для выбора эффективного сорбционного покрытия были изучены и сравнены четыре вида волокон ТФМЭ. Были изучены параметры, влияющие на эффективность ТФМЭ, такие, как время экстракции и преинкубации, температура экстракции, эффект природы растворителя, ионная сила, для получения оптимальных параметров. Метод был разработан с использованием загрязненных образцов воды в интервале концентрации 1 - 500 нг/л. Градуировочная зависимость линейна в изучаемом интервале концентрации с $r \geq 0,9925$. Предел обнаружения варьируется от 1,57 до 2,08 нг/л. Разработанная методика была апробирована на реальных образцах воды с озера загрязненных ХОП.

Ключевые слова: твердофазная микроэкстракция, газовая хроматография, масс-спектрометрия, хлорорганические пестициды.

\section{Е. Сайлауханұлы, Б.Н. Кенесов, Л. Карлсен, Д.Х. Қамысбаев ҚФМЭ/ГХ/МС әдісімен хлорорганикалық пестицидтерді суда анықтау}

Қатты фазалы микроэкстракциямен (ҚФМЭ) үйлескен масс-спектрометрлі газды хроматография (ГХ/МС) әдісі су анализі үшін зерттелді. Хлорорганикалық пестицидтер (ХОП), p,p-ДДТ, p,p-ДДД және р,p-ДДЭ ГХ/ МС әдісімен анализденді. Эффективті сорбциялық қаптаманы таңдау мақсатымен ҚФМЭ төрт түрлі талшығы зерттелді және салыстырылды. ҚФМЭ эффективтілігіне әсер ететін параметрлер, экстракция және преинкубация уақыты, экстракция температурасы, еріткіш табиғатының әсері, иондық күш, оптималды параметрлер таңдалуы үшін зерттелді. Әдіс ластанған су үлгілерімен 1 - 500 нг/л концентрациялар интервалында жасалды. Градуирлі тәуелділік зерттелетін концентрациялар интервалында сызықты және $r \geq 0,9925$. Анықтау шегі 1,57ден 2,08 нг/л аралығында болады. Әзірленген әдіс ХОП ластанған шынайы су үлгілерінде сыналды.

Түйін сөздер: қатты фазалы микроэкстракция, газды хроматография, масс-спектрометрия, хлорорганикалық пестицидтер.

\section{Introduction}

Organochlorine pesticides (OCPs), were widely used worldwide in past century and large amounts of these OCPs were piled up in various storage facilities [1] which today may be more or less destroyed [1]. Today OCPs are banned according to the Stockholm Convention [2] due to their very persistent and 
bioaccumulating nature. They fall into the group of so-called $\mathrm{vPvB}$ compounds as referred to the European chemicals regulation system REACH [3].

OCP have significant influence on both the environment and the human health [4]. Thus, when introduced into the body, the majority of OCPs is transported by the bloodstream and accumulates in the fatty tissues, liver, spleen, heart, brain, kidneys, adrenal glands, and lungs [4].

Despite the fact that the use of OCPs in general was banned as early as in the 1970's, they are, due to their high persistence, still found in many environmental samples including both soil and water as well as in biological samples [5].

Apparently aquatic systems may be directly involved in the distribution of OCPs in the environment. Thus, OCPs are still be found in many water bodies [6].

Previous studies $[5,6]$ reported findings of DDT in water, water plants, invertebrates, fish tissue, and sediments in more than $1 / 3$ of all surveyed water reservoirs in Kazakhstan. Thus, Nurzhanova et.al. [1,7] reported the identification of $p, p^{\prime}$-DDE in lake samples located $100 \mathrm{~m}$ from storehouses in the village of Beskainar in Talgar rayon (Almaty oblast, Kazakhstan) with an average concentration of 114 $\mu \mathrm{g} / \mathrm{L}$. In this context it is also worthwhile to note that Jensen et. al. [8] reported elevated of OCPs levels not only in environmental samples but also in blood lipids of children, in the Aral Sea region in Kazakhstan. The concentrations were found to be up to 20 times above maximum allowable concentration.

Analyses of OCPs in aqueous samples typically involve extraction of the compounds [9], which is often hampered by strong interaction between the OCPs and particulate matter and dissolved organic material.

The analyses of trace amounts of organic contaminants in environmental samples with complex matrix may thus require time consuming extraction and pre-concentration procedures, which is often the limiting step of the overall analytical method [10]. This disadvantages may, however, be overcame by applying a one-step extraction technique based on solid-phase microextraction (SPME) [11]. Thus, SPME can help overstep more traditional sample preparation procedures. Studies have shown that SPME apparently is well suited for the analyses of pesticides residues [12].

The application of SPME for the analysis of OCPs in water has been reported by several groups [12-15]. The majority of the studies applied a direct immersion of the SPME fiber into water.
Other studies [16,17] applied microwave extraction technique in combination with SPME. Headspace SPME (HSSPME) for analysis of OCPs in various environments has successfully been applied by Lambropoulou and others $[9,18]$.

In the present paper we describe an application of headspace solid-phase microextraction applying gas chromatography with mass spectrometry as detection system (HS-SPME/GC-MS) for the analysis of $p, p^{\prime}$-DDT and its metabolites $p, p^{\prime}$-DDE and $p, p^{\prime}$-DDD in water samples.

\section{Experimental}

\section{Reagents and materials}

OCPs standards $(100 \mu \mathrm{g} / \mathrm{ml})$ were obtained from "Lezart" (Almaty, Kazakhstan). A standard working solution was prepared in 2-propanol containing $p, p^{\prime}$-DDE, $p, p^{\prime}$-DDD, and $p, p^{\prime}$ 'DDT, all in concentrations of $1 \mathrm{mg} / \mathrm{L}$. Solvents were analytical reagent grade and stored at $4^{\circ} \mathrm{C}$. Working solutions of pesticides were prepared daily by appropriate dilutions with double-distilled water. Eight OCPs standard solutions in 2-propanol containing 0.1, $1.0,3.0 ; 5.0 ; 10 ; 30$ and $50 \mathrm{mg} / \mathrm{L}$ were prepared, respectively. Eventual stock solution of0.1, 0.5, 10, $30,50,100,300$ and $500 \mathrm{ng} / \mathrm{L}$, respectively, were prepared by dilution in water.

Four types of SPME fibers, i.e., $100 \mu \mathrm{m}$ poly(dimethylsiloxane) (PDMS), 65- $\mu \mathrm{m}$ PDMS/ divinylbenzene (PDMS/DVB), $85 \mu \mathrm{m}$ carboxen/ poly(dimethylsiloxane) (CAR/PDMS), and $85-\mu \mathrm{m}$ divinylbenzene/carboxen/poly(dimethylsiloxane) (DVB/CAR/PDMS) were obtained from Supelco (Bellefonte, PA, USA). All fibers were conditioned in the hot injector port of the gas chromatograph at $240-280{ }^{\circ} \mathrm{C}$ for 0.5 to $1 \mathrm{~h}$ prior to use in accordance with the recommendations of the manufacturer.

\section{Sample preparation}

Artificial water samples were prepared by spiking appropriate volumes of double-distilled water with $10 \mu \mathrm{L}$ of the above mentioned DDT/DDE/DDD stock solution in 2-propanol for optimization of the SPME process. The use of 2-propanol as the solvent of choice for the stock solution was due to the relatively high solubility of the compounds under investigation in this solvent compared to other polar solvents such as, e.g., ethanol and acetonitrile.

\section{GC-MS conditions}

Gas chromatography-mass spectrometry analyses of $p, p$ '-DDT and its metabolites were performed 
using a 6890/5973N (Agilent technologies, USA) system equipped with a $30 \mathrm{~m} \times 0.25 \mathrm{~mm}$ DB-1 capillary column with a $0.25 \mu \mathrm{m}$ film thickness (Agilent, USA) and split/splitless inlet working in splitless mode at $250^{\circ} \mathrm{C}$. Temperature program: from $40^{\circ} \mathrm{C}(3 \mathrm{~min})$ to $160^{\circ} \mathrm{C}$ using a $20^{\circ} \mathrm{C} \mathrm{min}$ ${ }^{1}$ ramp followed by a $3^{\circ} \mathrm{C} \mathrm{min}^{-1}$ ramp to $275^{\circ} \mathrm{C}$. Total run time was 48.33 min. Helium (grade "A", Orenburg-Techgas, Orenburg, Russia) was used as carrier gas with a constant flow rate of $1 \mathrm{~mL} \mathrm{~min}$ 1. The mass spectrometric detection was performed using selected ion monitoring (SIM) mode using ions at $\mathrm{m} / \mathrm{z} 235$ ( $p, p^{\prime}$-DDD, and $p, p^{\prime}$-DDT), 246 $\left(p, p^{\prime}\right.$-DDE $)($ dwell time $=50 \mathrm{~ms})$.

The gas chromatograph was equipped with a Combi-PAL autosampler (CTC Analytics AG, Switzerland) with a 32-position tray, agitator, SPME fiber holder and a conditioning station.
Automated headspace SPME procedure

Automated HS SPME extractions applied the Combi-PAL autosampler using $20 \mathrm{~mL}$ sealed vials. In each vial, $1 \mathrm{~mL}$ of standard solution in doubledistilled water and $0.35 \mathrm{~g} \mathrm{NaCl}$ were mixed. SPME was conducted at $95^{\circ} \mathrm{C}$ for $60 \mathrm{~min}$ at an agitation rate of $500 \mathrm{rpm}$. Analytes were thermally desorbed from the SPME fiber in the $\mathrm{GC}$ inlet at $240{ }^{\circ} \mathrm{C}$ for $5 \mathrm{~min}$.

\section{Results and discussion}

\section{Selection of SPME fiber}

To select the most optimal fiber for the HSSPME analysis of the three OCPs, we studied four different types of fiber coatings including PDMS, PDMS/DVB,CAR/PDMS and DVB/CAR/PDMS (see experimental section for details).

Fig. 1 illustrates the effect of SPME fibers on the efficiency of OCPs.

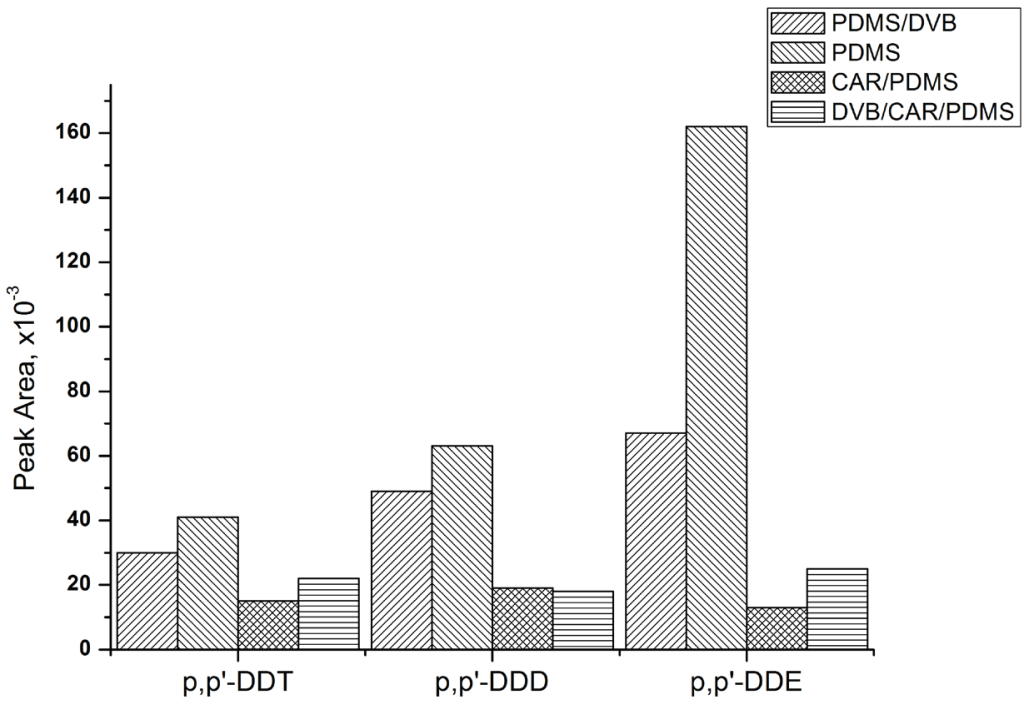

Figure 1 - Extraction efficiency (60 min)of $p, p$-DDE, $p, p$-DDD, and $p, p$-DDT respectively by four different SPME fibers

Application of the CAR/PDMS and DVB/ CAR/PDMS fiber coatings showed general low extraction efficiency for the 3 compounds being investigated. It is obvious (figure 1) that the PDMS fiber displays the highest extraction efficiency for the 3 compounds, especially pronounced for DDE whereas the efficiency of PDMS and PDMS/DVB are comparable in the cases of DDT and DDD. This maybe explained by the high hydrophobicity of these fiber coatings and, consequently, higher affinity for hydrophobic compounds. On this background, the PDMS fiber coating was chosen for further experiments.

\section{Optimization of extraction temperature}

Increase of extraction temperature can significantly increase the efficiency of SPME of analytes from the water due to the increased vapor pressure of the substances, especially for semi-volatiles.

To study the effect of temperature on the extraction efficiency of DDT/DDD/DDE, extraction 
temperatures $65,75,85$ and $95^{\circ} \mathrm{C}$ were investigated.

Increased temperature leads, as expected, to an increase in the response of all three compounds (figure 2). Obviously, extraction temperature of $95^{\circ} \mathrm{C}$ is the maximum allowed for the analysis of aqueous samples, which is thus chosen for further experiments.

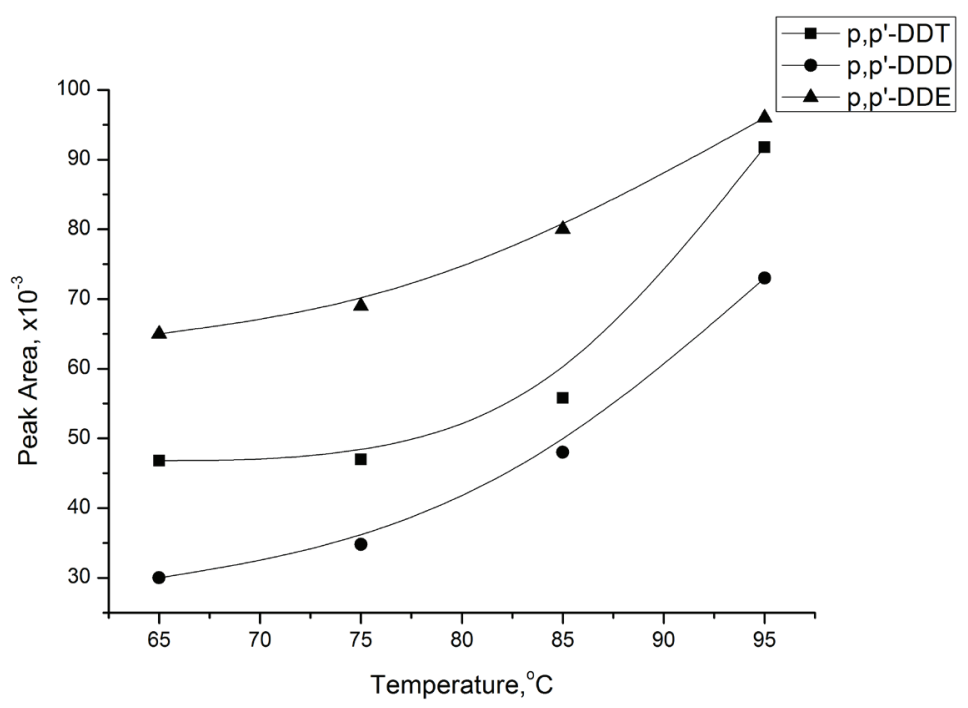

Figure 2 - Extraction efficiency of DDT, DDD and DDE as function of extraction temperature

\section{Optimization of extraction and pre-incubation time}

In order to transfer an analyte to the headspace, it is necessary to heat the sample before extraction. In the present case the OCPs studied exhibit low solubility and volatility, so heating prior to extraction obviously enhance analyte transfer between liquid and gaseous phases. To determine the optimal pre-incubation time, water samples containing OCPs in a concentrations of $100 \mathrm{ng} / \mathrm{L}$ were analyzed using extraction times of $0 ; 5$; $10 ; 15 ; 20 ; 25$ and 30 min. Figure 3 illustrates the pre-incubation time profiles of OCPs using the $100-\mu \mathrm{m}$ PDMS fiber. The pre-incubation time of 5 min was selected as optimal.

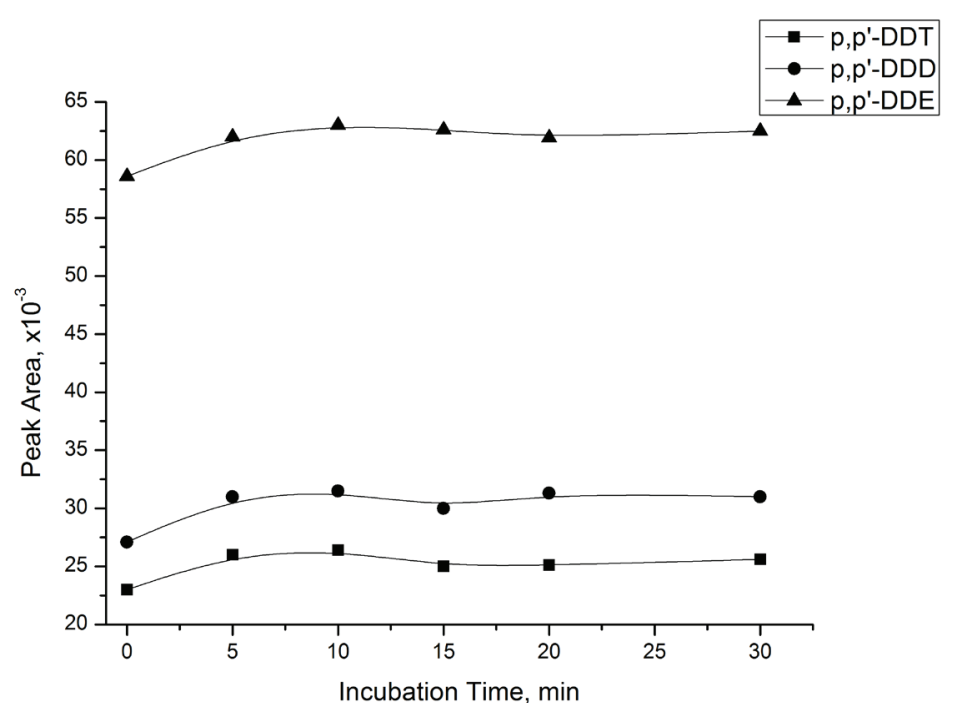

Figure 3 - The pre-incubation time profiles 
Increasing extraction time typically leads to an increasing response of analytes, and consequently, to reducing detection limits. However, the increase of extraction time can also lead to a proportional increase of quantitative determination of error due to the limited capacity of the polymer coating [11].

To determine the optimal extraction time, water samples containing OCPs in a concentration of 100 $\mathrm{ng} / \mathrm{L}$ were analyzed using extraction times of 5,10 , $15,20,25,30,40$ and $60 \mathrm{~min}$. Figure 4 illustrates the extraction time profiles of OCPs using the $100-\mu \mathrm{m}$ PDMS fiber at the extraction temperature of $95^{\circ} \mathrm{C}$. The equilibrium in the system is reached after 60 min. The long equilibration time for OCPs can be explained by their low water solubilities and high Kow values [11].

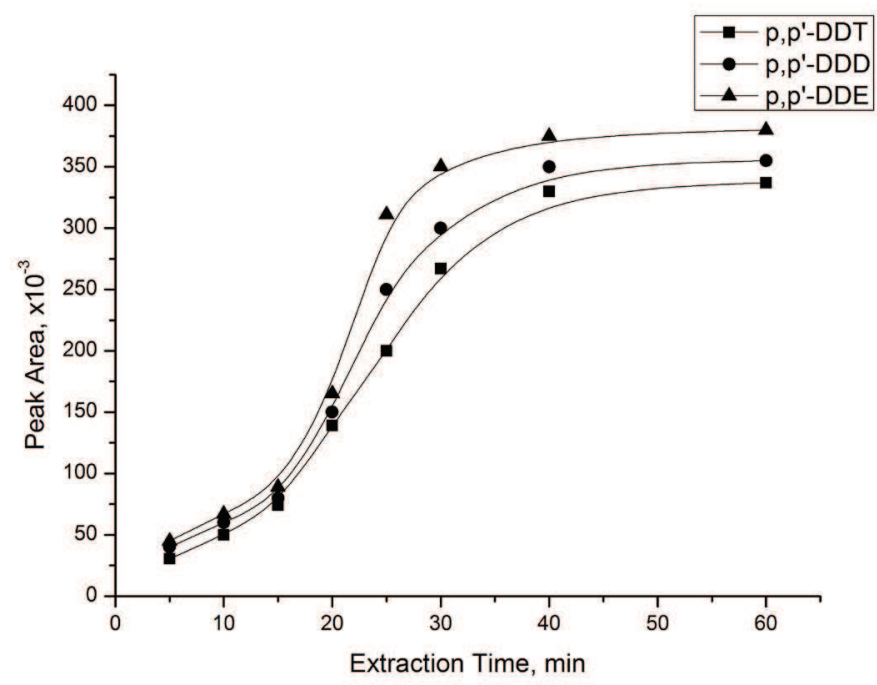

Figure 4 - The SPME extraction time profiles for OCPs with a 100- $\mu$ m PDMS fiber

Therefore, an extraction time of $60 \mathrm{~min}$ was selected to analysis of OCPs water samples.

\section{Effect of addition of an organic solvent and water}

Due to the fact that the 3 compounds studied are all very soluble in organic solvents, such as hexane, ethyl ether, methanol, and acetone whereas the water solubility is very low, a small amounts of organic solvent, not more $20 \%$ [14] apparently is necessary to produce the homogeneous water samples to be analyzed. However, it is not recommended to use PDMS fibers with non-polar organic solvents such as hexane, dichloromethane and diethyl ether to avoid swelling of fiber coatings. Consequently these solvents a priori were excluded. Further, we needed a solvent that is freely miscible with water. It should also be taken into account that the increase of temperature will promote vaporization of the organic solvent. To study the effect of polar organic solvents, we studied 2-propanol, ethanol and acetonitrile, respectively.

Figure 5 illustrates the effect of solvent nature on GC-MS response of DDT, DDD and DDE, respectively, compared to that applying pure water. It is immediately disclosed (figure 5) that 2-propanol apparently should be the solvent of choice for these studies. 


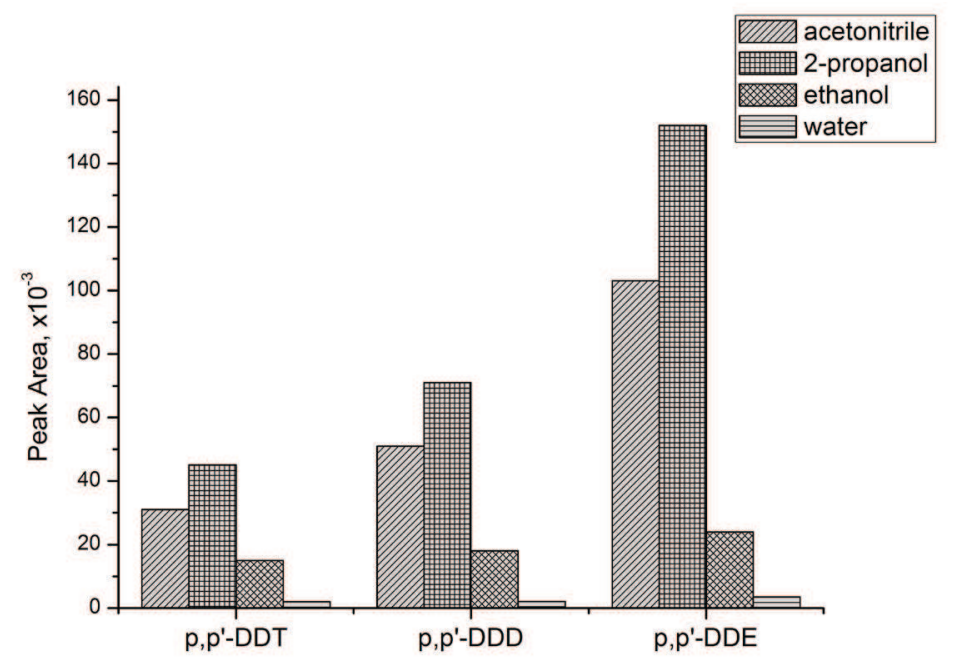

Figure 5 - Effect of solvent nature to response of DDT, DDD and DDE, added to the water sample to be analyzed

\section{Effect of ionic strength}

Increase of ionic strength of a water sample typically provides an increased efficiency of SPME [2] due a so-called salting out effect. Ionic strength was adjusted by adding exact amount of $\mathrm{NaCl}$ :
$0.05 ; 0.10 ; 0.15 ; 0.25$ and $0.35 \mathrm{~g}$ to $1 \mathrm{~mL}$ sample containing analytes in concentration of $100 \mathrm{ng} / \mathrm{L}$. All experiments were performed in duplicate and the results were compared to control samples without salt. The $\mathrm{pH}$ value of the samples was close to 7 .

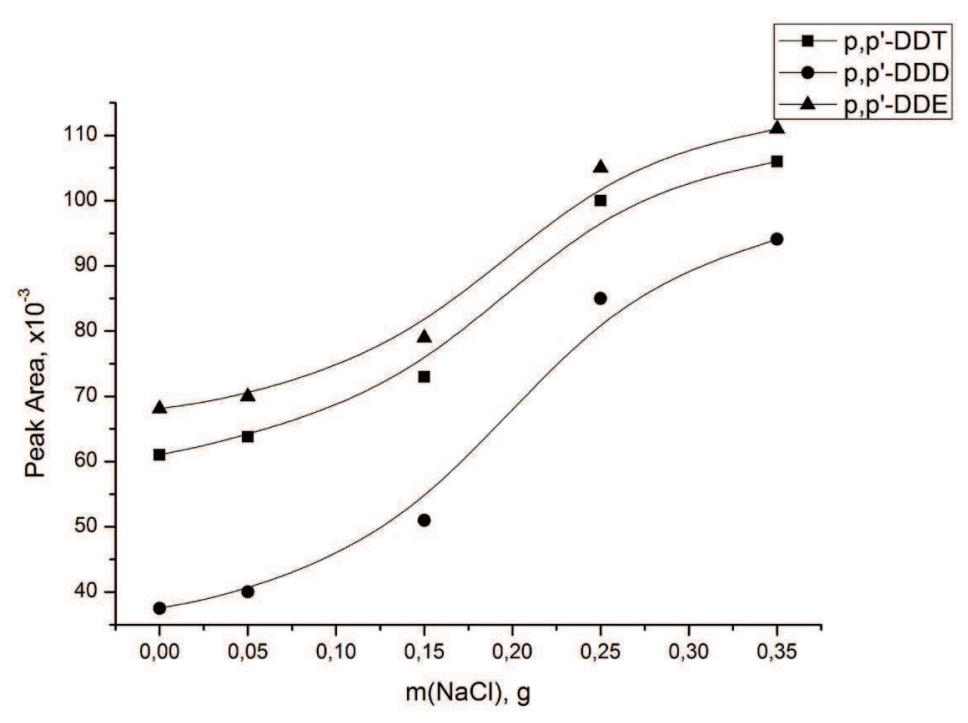

Figure 6 - Salting out effect for DDT, DDD and DDE, respectively

Not surprisingly we find that salting out significantly influences the GC-MS responses (figure 6). Hence, further analyses were applying adding $0.35 \mathrm{~g} \mathrm{NaCl}$ to the single samples prior to extraction and subsequent analysis. 


\section{Calibration Curves}

For quantitative determination of OCPs, calibration plots were obtained over the concentration range of $10-500 \mathrm{ng} / \mathrm{L}$ (for $p, p^{\prime}-\mathrm{DDT}$ ) and 5 $500 \mathrm{ng} / \mathrm{L}\left(p, p\right.$ '-DDD and $\left.p, p^{\prime}-\mathrm{DDE}\right)$, respectively. Calibration plots have close to perfect linearity (concentration vs. peak area with correlation coefficients, $\mathrm{R}^{2}=0.9925$ ( $p, p^{\prime}$ 'DDT), 0.9964 ( $p, p^{\prime}-$ DDD) and 0.994 ( $p, p^{\prime}$-DDE), respectively. The detection limits were calculated using US EPA 40CFR136 protocol and varied from 1.57 to 2.08 $\mathrm{ng} / \mathrm{L}$. The precisions were ranged between 0.03 and 0.06 , which is satisfactory for determining OCPs in water samples. The recoveries of OCPs except the $p, p$ '-DDE showed a satisfactory recovery (table 1 ).

Table 1 - Data from calibration curves

\begin{tabular}{|l|l|l|l|l|l|}
\hline Pesticides & Linear range, $\mathrm{ng} / \mathrm{L}$ & $\mathrm{R}^{2}$ & LOD, ng/L & RSD., $\%(\mathrm{n}=3)$ & Recovery, \% \\
\hline$p, p^{\prime}$-DDT & $10-500$ & 0.9925 & 1.57 & 7.37 & 71 \\
\hline$p, p^{\prime}$-DDE & $10-500$ & 0.994 & 1.7 & 10.9 & 45 \\
\hline$p, p^{\prime}$-DDD & $10-500$ & 0.9964 & 2.08 & 7.74 & 64 \\
\hline
\end{tabular}

\section{Analysis of authentic samples}

Authentic samples were obtained from a lake and a stream located in the close vicinity of a former storehouse of pesticides in village Beskainar (Talgar district, Almaty oblast). A small stream falls into lake from the spring through the storehouse. The lake is located at position $43^{\circ} 13^{\prime} 19.78^{\prime \prime} \mathrm{N}, 77^{\circ}$ 6'39.83' E at a height of $1471 \mathrm{~m}$ above the sea level and storehouse is located at position $43^{\circ} 13^{\prime} 16.31^{\prime \prime}$ $\mathrm{N}, 77^{\circ} 6,50.55^{\prime \prime} \mathrm{E}$ at a height of $1487 \mathrm{~m}$.

All real samples were prepared according to the above mentioned procedure and analyzed by SPME/ GC/MS. $p, p$ '-DDE, $p, p$ '-DDD, and $p, p$ '-DDT were found in all samples. The highest concentration amounted to $3.49 ; 12.19$ and $2.16 \mathrm{ng} / \mathrm{L}$ for DDT, DDE and DDD, respectively.

\section{Conclusion}

HS-SPME-GC/MS analyses of OCPs in water samples were optimized. Determination procedures with $100 \mu \mathrm{m}$ PDMS fiber consist $60 \mathrm{~min}$ extraction of $1 \mathrm{ml}$ water at $95^{\circ} \mathrm{C}$ with agitation (500 rpm) and $0.35 \mathrm{~g}$ salt addition without $\mathrm{pH}$ adjustment. For quantitative determination calibration plots were built up over the concentration range of $10-500$ $\mathrm{ng} / \mathrm{L}$ (for $p, p^{\prime}-\mathrm{DDT}$ ) and $5-500 \mathrm{ng} / \mathrm{L}\left(p, p^{\prime}-\mathrm{DDD}\right.$ and $p, p$ '-DDE). The method was approved in real samples taken from contaminated site. This method is being suitable for routine analysis.

\section{References}

1 Nurzhanova A., Kulakow P., Rubin E., Rakhimbayev I., Sedlovskiy A., Zhambakin K. Kalugin S, Kolysheva O., Erickson L. Phytoremediation of contaminated soil in Kazakhstan // Application of Phytoremediation for Cleanup of Industrial, Agricultural and Wastewater Contamination. Eds P.A.Kulakow, V.V. Pidlisnyuk. 2010: Springer Science - P. 87-109.

2 Stockholm Convention on persistent organic pollutants // - (http://www.pops.int/documents/convtext/convtext_en.pdf.)

3 Regulation (EC) No 1907/2006 of the European Parliament and of the Council of 18 December 2006383 concerning the Registration, Evaluation, Authorisation and Restriction of Chemicals (REACH). - 2006. - // (http://eur-lex.europa.eu/LexUriServ/site/en/ oj/2006/1_396/1_39620061230en00010849.pdf; Accessed Nov. 2012).

4 Chopra A.K., Kuma M., Chamoli S. Bioaccumulation of organochlorine pesticides in aquatic system-an overview // Environmental Monitoring Assessment. - 2011. - Vol. 173. - P.905-916.

5 Ayas Z., Barlas N., Kolankaya D. Determination of organochlorine pesticide residues in various environments and organisms in Goksu Delta, Turkey // Aquatic Toxicology. - 1997. - Vol. 39. - P.171-181.

6 IPEN, 2004a. Kazakhstan Country Situation Report, English Summary, International POPs Elimination Project // - (http:// www.ipen.org/ipepweb1/library/ipep_pdf_reports/1kaz\%20kazakhstan\%20country\%20situation\%20report\%20english.pdf (accessed Mar.2012))

7 Nurzhanova A., Zhambakin K., Kalugin S. Obsolete pesticides and application of colonizing plant species for remediation of contaminated soil in Kazakhstan // Environmental Science Pollution. - 2012. - Res DOI 10.1007/s11356-012-1111-x

8 Jensen, S., Mazhitova, Z. and Zetterstrцm, R.,1997. Environmental pollution and child health in the Aral Sea region in Kazakhstan. // The Science of Total Environment. - 1997. - Vol. 206. - P.187-193. 
9 Ratola N., Santos L., Herbert P., Alves A. Uncertainty associated to the analysis of organochlorine pesticides in water by solidphase microextraction/gas chromatography-electron capture detection-evaluation using two different approaches // Analytica Chimica Acta. - 2006. -Vol. 573-574.

10 Muir D., Sverko E. Analytical methods for PCBs and organochlorine pesticides in environmental monitoring and surveillance: a critical appraisal. // Analytical and Bioanalytical Chemistry. - 2006. - Vol.386. - P. 769-789.

11 Pawliszyn J. Handbook of Solid Phase Microextraction. - 1st edition. - Elsevier, 2012. - P. 477.

12 Beltran J., Lopez F.J., Hernandez F. Solid-phase microextraction in pesticide residue analysis // Journal of Chromatography A. - 2000. - Vol.885. - P.389-404.

13 Magdic S., Pawliszyn J. Analysis of organochlorine pesticides using solid-phase microextraction // Journal of Chromatography A. $-1996 .-$ Vol.723. - P.111-122.

14 Beceiro-Gonzalez E., Concha-Grana E., Guimaraes A., Goncëalves C., Muniategui-Lorenzo S., Alpendurada M.F. Optimisation and validation of a solid-phase microextraction method for simultaneous determination of different types of pesticides in water by gas chromatography-mass spectrometry // Journal of Chromatography A. - 2007. - Vol.1141. - P.165-173.

15 Donga C., Zeng Z., Yang M. Determination of organochlorine pesticides and their derivations in water after HS-SPME using polymethylphenylvinylsiloxane-coated fiber by GC-ECD // Water Research. - 2005. - Vol.39. - P.4204-4210.

16 Li H.-P., Li G.-C., Jen J.-F. Determination of organochlorine pesticides in water using microwave assisted headspace solid-phase microextraction and gas chromatography // Journal of Chromatography A. - 2003 - Vol.1012. - P.129-137.

17 Qiu C., Cai M. Ultra trace analysis of 17 organochlorine pesticides in water samples from the Arctic based on the combination of solid-phase extraction and headspace solid-phase microextraction-gas chromatography-electron-capture detector // Journal of Chromatography A. -2010. - Vol.1217. - P.1191-1202.

18 Lambropoulou D. A., Konstantinou I. K., Albanis A. T. Recent developments in headspace microextraction techniques for the analysis of environmental contaminants in different matrices // Journal of Chromatography A. - 2007. - Vol.1152. - P.70-96. 